\title{
Outbreak Investigation Following the 2015 Earthquake Disaster in Nepal
}

Geeta Shakya, ${ }^{1}$ Baburam Marasini, ${ }^{2}$ Khem Bahadur Karki, ${ }^{3}$ Bishnu Prasad Upadhaya, ${ }^{1}$ Jyoti Acharya, ${ }^{1}$ Shailaja Adhikari, ${ }^{1}$ Rosham Manjhi, ${ }^{1}$ Laxman Maharjan, ${ }^{1}$ Lilee Shrestha, ${ }^{1}$ Kamal Ranabhat, ${ }^{1}$ Sujan Babu Marahatta, ${ }^{4}$ Bikal Shrestha, ${ }^{5}$ Meghnath Dhimal ${ }^{3}$

${ }^{1}$ National Public Health Laboratory, Teku, Kathmandu, ${ }^{2} E$ pidemiology and Disease Control Division, Teku, Kathmandu, ${ }^{3} \mathrm{Nepal}$ Health Research Council, Kathmandu, ${ }^{4}$ Manmohan Memorial Institute of Health Sciences, Kathmandu, ${ }^{5}$ Nepalese Army Institute of Health Sciences, Sanobharyang, Kathmandu, Nepal.

\section{ABSTRACT}

\begin{abstract}
Background: Infectious disease outbreaks following natural disasters are reported in literature. Outbreaks were documented following natural disasters in many countries including Haiti. Such possibility following 2015 Nepal earthquake was a public health concern. Risk factors needed evaluation by post-disaster outbreak investigation. Hence, present study was undertaken to investigate potentials for such outbreak and to generate evidence for public health intervention.
\end{abstract}

Methods: The study was conducted between April - May, 2015, with the cooperation of National Public Health Laboratory, Epidemiology and Disease Control Division, Nepal Health Research Council and the Chinese team. Rapid Response Teams visited earthquake affected districts and collected samples for analysis. Syndromic surveillance approach was followed. Samples were collected from syndromic patients under supervision. Those sick prior to earthquake or receiving treatment were excluded. Blood, stool and throat swab samples, as indicated, were collected. Drinking water and food samples including captured live mosquitoes from inhabited areas were obtained for study with the help of EDCD. Laboratory analysis was performed at the NPHL.

Results: Total samples were 360 (114 biological, 246 environmental). Salmonella spp. was detected in two and Varicella zoster in one blood sample. Influenza B virus was detected in one throat swab. Rota virus was detected in two, Shigella dysenteriae in one and Salmonella spp. in one stool sample. No pathogen detected in water or food samples. Mosquitoes tested negative for dengue virus.

Conclusions: Post-earthquake outbreak investigated in disaster phase-2. Diarrheal, enteric fever pathogens and Influenza B virus were detected. Environmental samples tested negative for pathogens. Vigilance is necessary for other risk factors.

Keywords: Investigation, natural disaster; outbreaks.

\section{INTRODUCTION}

Infectious disease outbreaks may follow natural disasters. ${ }^{1}$ Increased diarrheal diseases after flooding in Mozambique in $2000,{ }^{2}$ after earthquake in El Salvador in 2001, ${ }^{3}$ after the Bam earthquake in Iran in 2003, ${ }^{4}$ following tsunami in Calang, Indonesia in 2004, ${ }^{5}$ following Indian tsunami in Thailand in $2004,{ }^{6}$ and following earthquake in Pakistan in $2005^{7}$ are a few documented examples. Similarly, outbreak of cholera epidemic, nine months after the earthquake in Haiti in 2010 caused high case-fatality ${ }^{8}$.

On 25 April 2015, a 7.6 magnitude earthquake devastated Nepal. In the 14 most affected districts nearly 84 percent of the health facilities were completely damaged resulting in disorganization of service delivery response, ${ }^{9}$ heightening vulnerability for spread of infectious diseases. Hence, the present study was carried out to find out any potential for infectious disease outbreak following this earthquake disaster, and to identify any focus or reservoir for impending post-disaster epidemic.

\section{METHODS}

This study was conducted with the cooperation of National Public Health Laboratory, Epidemiology and Disease Control Division, Nepal Health Research Council and the Chinese team in the period between April to May, 2015. Rapid Response Teams (RRTs) each consisting 
of three laboratory workers and two epidemiologists collected samples from the sites in the most affected districts taking all necessary bio-safety precautions. Laboratory disposables and transport media for culture were provided by the NPHL along with the pre-prepared checklist of procedures according to the NPHL guidelines, 2015. ${ }^{10}$

A validated list of districts designated ' 14 most affected districts' was obtained as shown (Table 1 ) and the study was focused on those locations. ${ }^{11}$ Clinical laboratory and environmental investigations were carried out as per the NPHL Guidelines for the Laboratory Investigation of Outbreaks, 30 June 2015, Kathmandu, Nepal. All patients with syndromic features as enlisted (Table 2 ), suspicious of infection with organisms of epidemic potential, who attended the health facilities within the districts were included in the study. Persons already sick prior to the earthquake disaster or those already receiving treatment fell into the exclusion criteria. Informed consent was obtained from the patients for participation in the study. Ethical approval was obtained from the ethical committee of the NHRC. Biological specimens consisted of samples of blood and stool, and throat swab specimens obtained by laboratory personnel in consultation with the attending doctor, according to earlier planning.

\begin{tabular}{|c|c|}
\hline No. & Name of most affected districts \\
\hline 1. & Gorkha \\
\hline 2. & Kavrepalanchok \\
\hline 3. & Dhading \\
\hline 4. & Nuwakot \\
\hline 5. & Rasuwa \\
\hline 6. & Sindupalchok \\
\hline 7. & Dolakha \\
\hline 8. & Ramechhap \\
\hline 9. & Okhaldunga \\
\hline 10. & Makwanpur \\
\hline 11. & Sindhuli \\
\hline 12. & Kathmandu \\
\hline 13. & Bhaktapur \\
\hline 14. & Lalitpur \\
\hline
\end{tabular}

Table 2. List of syndromic-cases with suspicious epidemic potential. ${ }^{10}$

No. Name of syndromic-cases with suspicious epidemic potential

1. Acute watery diarrhea (rice watery stool with/ without vomiting)

2. Acute bloody diarrhea (with fever)

3. High grade fever with diarrhea (suspected enteric fever)

4. Other diarrhea

5. Slight fever with jaundice

6. Acute respiratory infection (ARI/ILI/SARI)

7. High fever with or without hemorrhage/rash (suspected arboviral infection)

8. Fever with chills (suspected malaria)

Environmental samples consisted of water and food samples and live mosquitoes captured from the inhabited areas for entomological and immunological study. Water samples from drinking water sources were collected with the standard operating procedure for environmental investigation. Samples of water were obtained from shallow well, deep boring well, natural spring, bottled water, with or without any purification by filtering or use of chemical water purifiers for drinking.

All collected specimens were labeled, preserved and transported expeditiously, to the NPHL for appropriate laboratory tests. Testing of all samples was done following the standard operating procedures at the NPHL and the entomological unit of the EDCD as soon after arrival as possible. Bacterial isolations were done by direct inoculation into appropriate culture media, whereas immunological tests were performed by indirect methods (Eliza or Antigen Antibody detection tests). The data from results of the tests were tabulated and analyzed using appropriate statistical methods.

\section{RESULTS}

Total number of samples collected during the study was 360 (biological specimens 114 + environmental specimens 246). The type and number of specimens are given in Table 3 whereas, Table 4 shows the result of laboratory analysis of specimens.

Biological samples: Two blood samples showed growth of Salmonella spp., whereas, Varicella zoster was detected in one blood sample. Organisms identified in 
stool samples were Rota virus (in 2 samples), Shigella dysenteriae (in 1 sample) and Salmonella spp. (in 1 sample). The districts wherefrom the samples showing positive results were collected, are also enlisted (Table 4).
Environmental samples: No growth of any pathogen of public health importance was observed in the water or food samples. Virological tests for detection of pathogens in the captured mosquitoes were also negative for dengue virus.

Table 3.Type and number of samples.

\begin{tabular}{llll} 
Type of sample & Number (No.) & Type of sample & Number (No.) \\
\hline & Blood specimen (3) & & Water (230) \\
Biological samples\# & Stool specimen (59) & Environmental & Food (5) \\
& Throat swab (52) & samples & Captured mosquitoes (11) \\
& Total: 114 & Total: 246 \\
\hline
\end{tabular}

\begin{tabular}{|c|c|c|c|}
\hline Type of sample & Blood specimen & Stools specimen & $\begin{array}{l}\text { Throat swab } \\
\text { specimen }\end{array}$ \\
\hline $\begin{array}{l}\text { Pathogen } \\
\text { isolated/ } \\
\text { Name of district } \\
\text { where from } \\
\text { isolated }\end{array}$ & $\begin{array}{l}\text { Salmonella spp. }(\mathrm{n}=2) / \\
\text { Kathmandu, } \\
\text { Dhading. } \\
\text { Varicella zoster }(\mathrm{n}=1) / \text { Dhading }\end{array}$ & $\begin{array}{l}\text { Rota virus }(n=2) / \text { Kathmandu and Lalitpur. } \\
\text { Shigelladysenteriae }(n=1) / \text { Sindhupalchok. } \\
\text { Salmonella spp. }(n=1) / \text { Dhading. }\end{array}$ & $\begin{array}{l}\text { Influenza B } \\
\text { virus }(n=1) / \\
\text { Kathmandu }\end{array}$ \\
\hline
\end{tabular}

\section{DISCUSSION}

This study is an anticipatory investigation for identification of disease pathogens with epidemic potential following the 2015 earthquake disaster. Case findings were focused at the still functioning or makeshift health facilities in the earthquake-ravaged districts, which the community attended for their health care needs. The syndromic surveillance approach followed, as described in the NPHL guidelines ${ }^{10}$ is the prevalent method for outbreak investigation in public health practice. ${ }^{12}$

We concentrated on identifying pathogens, mainly with diarrheal or respiratory disease outbreak potential, which according to the World Health Organization (WHO), are the most common causes of mortality after a natural disaster, besides measles, malaria, and malnutrition. ${ }^{13}$ In the past, outbreaks of similar type have been the major causes of morbidity and mortality in the periods subsequent to natural disasters elsewhere in the world. ${ }^{14}$

A total of 360 samples were collected during the present study, comprising of biological as well as environmental specimens. Two Salmonella spp. and one Varicella zoster organism were identified in blood specimens from Kathmandu and Dhading districts, respectively. Rota virus in two stool specimens (from Kathmandu and Lalitpur districts), Shigella dysenteriae and Salmonella spp (in two stool specimens from Sindhupalchok and Dhading districts, respectively) tested positive. Of the
52 throat swab samples collected from 12 districts, only one sample from Kathmandu tested positive for Influenza B virus. Environmental samples, 246 in number (comprising of 230 water samples +5 food samples + 11 live mosquitoes captured from inhabited localities) tested negative for pathogenic organisms of public health importance.

Only a small number of patients attending the health facilities had syndromic features and qualified for the inclusion criteria. This diminutive number may be indicative of a smaller population displacement and consequently less risk for outbreaks. ${ }^{14,15}$

Overwhelming number of patients attending the health facilities were trauma victims and excluded from syndromic surveillance. Infectious disease transmission or outbreaks may be seen days, weeks or even months after the onset of the disaster. The present study was undertaken in the outbreak phase-2, the post-impact phase (which is about 4 weeks post-disaster) ${ }^{14}$ with the surveillance focused on the first waves of infectious diseases (air-borne, food-borne, and/or water-borne infections) that might emerge as an early warning of ensuing epidemic. ${ }^{15}$

It is interesting to note that all the environmental samples tested negative for pathogens thereby indicating that the immediate environment was a negligible threat for any post-earthquake outbreak, despite the massive 
environmental disruption and heightened vulnerability of the victims.

The pathogens identified in the biological samples existed in micro-clusters indicative of their endemicity. Detecting cases of diseases that occur endemically may be falsely interpreted as an early epidemic. ${ }^{14}$ This occurs in the absence of background data and needs consideration while formulating strategy for public health intervention. So, the outcome of the present study needs to be viewed from the perspective that infectious disease outbreaks result secondarily from exacerbation of disease risk factors. In addition, the importance of identifying and minimizing these risk factors cannot be overemphasized, although only micropockets of infection have been identified in the present study.

Review of literature shows that numerous diarrheal outbreaks have followed natural disasters. Diarrheal outbreak due to Salmonella enterica serotype Paratyphi A was associated with flooding in Indonesia in $1992,{ }^{16}$ diarrhea was reported amongst the December 2004 tsunami victims of Aceh province, Indonesia in 2004, ${ }^{17}$ Vibrio cholerae (01 Ogawa and 01 Inaba) and enterotoxigenic Escherichia coli were isolated in postflooding diarrheal outbreak in Bangladesh in 200418 and Vibrio cholerae (01 Ogawa) was incriminated in post-flooding diarrheal epidemic in West Bengal in 1998 cholera outbreak following floods in a northern district of West Bengal, ${ }^{19}$ and outbreak of acute watery diarrhea occurred after the 2005 earthquake in Muzaffarabad, Pakistan. ${ }^{20}$ Shigella species were the most commonly identified causes of diarrheal outbreak after the earthquake in Kocaeli, Turkey in August 1999. ${ }^{21}$ Monitoring of the incidence of such diseases and documenting of their impact on public health, helps to better understand and quantify the risk of outbreaks following natural disasters and this equally applies to the results of the present study.

\section{CONCLUSIONS}

All the environmental samples tested negative for pathogens whereas, pathogens identified in the biological samples existed in micro-clusters. Pathogens causing diarrheal disease and enteric fever were predominantly identified and only one sample from Kathmandu tested positive for Influenza B virus. Importance of identifying and minimizing the disease risk factors must be emphasized.

\section{ACKNOWLEDGMENTS}

We are grateful to all the patients who participated in the study and without whose cooperation and enthusiasm this study would not have been possible. We are also thankful to the staff of NPHL, EDCD and NHRC, who despite the inherent risks in the nature of outbreak investigation, collected the samples from the disasterhit districts and made this study a reality. Immense thanks are also due to Professor Dr. K. N. Shakya of Kathmandu Medical College who helped in the write up and drafted the final manuscript for submission.

\section{REFERENCES}

1. Kouadio IK, Aljunid S, Kamigaki T, Hammad K, Oshitani H. Infectious diseases following natural disasters: prevention and control measures. Expert Rev Anti Infect Ther. 2012;10(1): 95-104. [DOI] [Link]

2. Kondo H, Seo N, Yasuda T, Hasizume M, KoidoY, Ninomiya $\mathrm{N}$, et al. Post flood-infectious diseases in Mozambique. Prehosp Disaster Med. 2002;17:126-133. [PubMed]

3. Woersching JC, Snyder AE. Earthquakes in El-Salvador: A descriptive study of health concerns in a rural community and the clinical implication - part II. Disaster Manag Response.2004;2:10-13. [PubMed]

4. Akbari ME, Farshad AA, Asadi-Lari M. The devastation of Bam: an overview of health issues 1 month after the earthquake. Public Health.2004;118:403-8. [PubMed]

5. Brennan RJ, Kimba K. Rapid health assessment in Aceh Java district. Indonesia, following the December 2006 Tsunami. Emerg Med Australia. 2005;17:341-50. [PubMed]

6. Centers for Diseases Control and Prevention. Rapid health response, assessment and surveillance after a tsunami - Thailand, 2004-2005. MMWR Morbidity Mortality Weekly Report 2005;54:61-4. [Link]

7. World Health Organization. Acute watery diarrhea outbreaks. Morbidity Mortality Weekly Report 2005;1:6. [Full Text]

8. World Health Organization. Health action in crises. Haiti: response to the cholera outbreak [cited 2015 June 19]. Available from: http://www.who.int/hac/crises/hti/ highlights/ october2010/en/index.html

9. Government of Nepal, National Planning commission, Nepal earthquake 2015 Post Disaster Needs Assessment Vol. A: Key Findings, 2015 [Full Text]

10. NPHL, Guidelines for the Laboratory Investigation of 
Outbreak Investigation Following the 2015 Earthquake Disaster in Nepal

Outbreaks, 30 June 2015, Kathmandu, Nepal [Link]

11. Ministry of Home Affairs, Nepal. Nepal Earthquake 2072 Situation Update as of $11^{\text {th }}$ May, Major Highlights [cited 2015 July 29]. Available from: [Link]

12. Heffernan R, Mostashari F, Das D, Karpati A, Kulldorff M,Weiss D. Syndromic surveillance in publichealth practice, New York City. Emerg Infect Dis. 2004;10(5):858-64 [Link]

13. World Health Organization. Communicable diseases following natural disasters: risk assessment and priority interventions. 2006. Geneva. Available from: http:// www.who.int/diseasecontrol_emergencies/guidelines/ CD_Disasters_26_06.pdf

14. Watson JT, Gayer M, Connolly MA, Epidemics after natural disasters. Emerg Infect Dis. 2007;13(1) [Link]

15. Aljunid S, Kamigaki T, Hammad K, Oshitani H. Preventing and controlling infectious diseases after natural disasters, United Nations University, 2012. [Link]

16. Vollaard AM, Ali S, van Asten HA, Widjaja S, Visser LG, Surjadi C, et al. Risk factors for typhoid and paratyphoid fever in Jakarta, Indonesia. JAMA. 2004;291:2607-15. [Link]
17. Brennan RJ, Kimba K. Rapid health assessment in Aceh Jaya District, Indonesia, following the December 26 tsunami. Emerg Med Australas. 2005;17:341-50. [PubMed]

18. Qadri F, Khan AI, Faruque AS, Begum YA, Chowdhury F, Nair GB, Salam MA, Sack DA, Svennerholm AM. Enterotoxigenic Escherichia coli and Vibrio cholerae diarrhea, Bangladesh, 2004. Emerg Infect Dis. 2005, 11:1104-1107. [PubMed]

19. Sur D, Dutta P, Nair GB, Bhattacharya SK, Severe cholera outbreak following floods in a northern district of West Bengal. IIndian J Med Res. 2000,112:178-82. [PubMed]

20. Watson JT, Gayer M, Connolly MA. Epidemics after Natural Disasters. Emerging Infect Dis. 2007;13(1):1-5. doi:10.3201/eid1301.060779. [PMC]

21. Vahaboglu H, Gundes S, Karadenizli A, Mutlu B, Cetin S, Kolayli F, et al. Transient Increase in Diarrheal Diseases after the Devastating Earthquake in Kocaeli, Turkey: Results of an infect disease surveillance study. Clin Infect Dis. 2000;31(6):1386-9. [Link] 